\title{
Accessibility of hydroxyl groups in furfurylated wood at different weight percent gains and during Rhodonia placenta decay
}

\author{
Greeley Beck ${ }^{1} \mathbb{D} \cdot$ Callum Hill $^{1} \cdot$ Pierre Martin Cocher $^{2} \cdot$ Gry Alfredsen $^{1}$
}

Received: 18 February 2019 / Published online: 27 July 2019

(c) The Author(s) 2019

\begin{abstract}
Deuterium exchange was used to measure accessible hydroxyl $(\mathrm{OH})$ groups in furfurylated wood at different weigh percent gains (WPGs) and at different levels of mass loss caused by exposure to the brown-rot fungus Rhodonia placenta. The results from the deuterium exchange method showed that $\mathrm{OH}$ accessibility in furfurylated samples did not change with increasing WPGs. However, $\mathrm{OH}$ accessibility in furfurylated samples increased significantly after initiation of decay at commercial treatment level (mean WPG 32\%), which is attributed to degradation of crystalline cellulose regions and formation of new $\mathrm{OH}$ groups in lignin and the furfuryl alcohol polymer.
\end{abstract}

\section{Introduction}

Chemical wood modification imparts dimensional stability and decay resistance to the material. The mechanisms by which this occurs are thought to be related to the bulking of the wood cell wall and subsequent moisture exclusion. The volume occupied by the reagent in the cell wall reduces the cell wall moisture content below the optimum level for decay and, at the same time, holds the cell wall in a swollen state, imparting dimensional stability. The reaction of wood with furfuryl alcohol is classed as an impregnation modification because the reagent polymerises, to some extent, inside the cell wall. Furfuryl alchohol may also react with the wood cell wall $\mathrm{OH}$ groups, although this has yet to be definitively demonstrated. It is possible to determine whether the cell wall $\mathrm{OH}$ groups are involved in a reaction with a modifying agent by using deuterium exchange to determine accessible $\mathrm{OH}$ content. Although furfuryl alcohol contains $\mathrm{OH}$ groups, these are removed in the condensation reaction during polymerization, and $\mathrm{OH}$ groups will only occur at the chain ends. Deuterium exchange was used to determine reduction in $\mathrm{OH}$ content due to reaction with acetic anhydride (Popescu et al. 2014). Beck et al. (2017) showed that

Greeley Beck

greeley.beck@nibio.no

1 Department of Wood Technology, Norwegian Institute of Bioeconomy Research, PO Box 115, 1431 Ås, Norway

2 ENSTIB, University of Lorraine, 27 Rue Philippe Séguin, 88000 Épinal, France deuterium exchange can be successfully performed in an instrument designed for thermogravimetric analyses; the results for untreated and acetylated Pinus radiata agreed with literature data obtained in a DVS apparatus. The aim of this study was to use the deuterium exchange method provided by Beck et al. (2017) to investigate changes in $\mathrm{OH}$ content in sound, furfurylated wood and at different stages of brown-rot decay by Rhodonia placenta.

\section{Materials and methods}

\subsection{Wood material}

Pinus radiata (D. Don) sapwood boards were used to make cylindrical earlywood samples $(0.6 \mathrm{~cm}$ diameter, $1 \mathrm{~cm}$ height) according to Beck et al. (2018).

A proprietary furfuryl alcohol stock solution was supplied by Kebony ASA (Skien, Norway) and diluted to contain 10, 25 or $40 \%$ furfuryl alchohol. The samples were soaked in the solutions for 15 days, then wrapped in aluminium foil and cured at $120^{\circ} \mathrm{C}$ for 17 hours. The samples were leached according to EN 84 (1997) prior to decay testing.

\subsection{Fungal test}

Rhodonia placenta FPRL 280 (Fr.) Niemelä, K.H. Larss. $\&$ Schigel was used for the decay test. For details about the decay test see Beck et al. (2018). The only deviation from the method provided in Beck et al. (2018) was that the 
samples were harvested every 3 weeks until week 42 (not every 2 weeks until week 28 ).

\subsection{Deuterium exchange method}

The deuterium exchange method was performed according to Beck et al. (2017) but using the altered drying steps provided in Beck et al. (2018). Non-decayed samples included the following treatment levels: low $=\mathrm{WPG} 3.5 \pm 0.1$, medium $=$ WPG $22.2 \pm 0.3$, high $=$ WPG $30.4 \pm 0.5$ and unmodified radiata pine $(n=5)$. The data are presented in terms of $\mathrm{OH}$ content per unit cell wall mass, which requires a correction to be made to account for the extra mass due to the presence of the furfuryl polymer (Eq. 1):

$\mathrm{OH}_{\text {corr }}=\mathrm{OH}_{\text {meas }}(1+\mathrm{WPG} / 100)$

where $\mathrm{OH}_{\text {corr }}$ is the corrected $\mathrm{OH}$ content based upon number of $\mathrm{OH}$ groups per unit cell wall mass, $\mathrm{OH}_{\text {meas }}$ is the $\mathrm{OH}$ content based upon total sample mass, and WPG is the weight percentage gain of the sample due to reaction with furfuryl alcohol. Twenty-two samples of high treatment level (WPG 32.1 \pm 2.0 ) were analysed with different decay mass loss after exposure to $R$. placenta together with five nondecayed samples of the same treatment level.

\section{Results and discussion}

\subsection{Non-decayed, different levels of FA}

The hydroxyl accessibility of the non-decayed samples varied between 5.7 and $7.4 \mathrm{mmol} / \mathrm{g}$ (Fig. 1). No statistically significant differences in hydroxyl group accessibility were found between the treatment levels nor compared to the radiata pine control. The lack of variation in $\mathrm{OH}$ content at

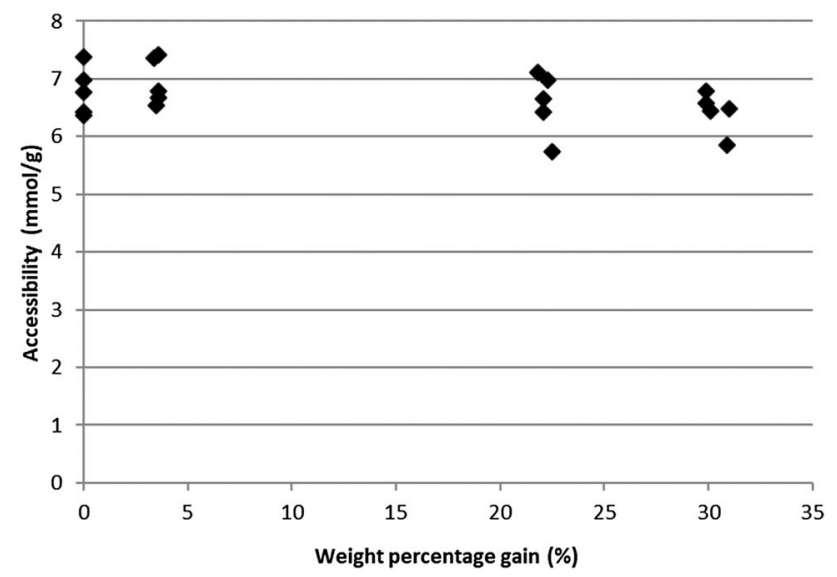

Fig. 1 Hydroxyl accessibility reported per unit cell wall mass for furfurylated wood at different WPGs and unmodified radiata pine different WPG levels and unmodified wood strongly suggests that there is no direct substitution of cell wall polymers and that retention of polymer in the cell wall is due to entanglement of the furfuryl polymers within the cell wall matrix. However, this does not definitely rule out grafting reactions with the lignin. Since addition of furfuryl alcohol to the wood did not increase the $\mathrm{OH}$ content, this is an indication that the polymer chains are relatively long, with a low proportion of terminal $\mathrm{OH}$ groups. There also is little evidence of masking of cell wall $\mathrm{OH}$ groups, which has previously benn reported for anhydride modified wood (Beck et al. 2017). According to the data presented here, there appears to be little effect upon cell wall accessible $\mathrm{OH}$ content due to modification with furfuryl alcohol.

\subsection{Rhodonia placenta decayed FA modified wood}

Rhodonia placenta is a frequently used model of brown-rot fungus in scientific research. The exact mechanisms regulating brown-rot decay are still not fully understood, but it is generally agreed that: 1) brown-rot fungi utilise a two-step system including initial non-enzymatic oxidation to depolymerise the cell wall components followed by enzymatic degradation, and 2) hydroxyl radicals produced via extracellular Fenton chemistry are important during incipient decay (Arantes and Goodell 2014). This early stage decay during brown rot causes significant strength loss (Winandy and Morrell 1993), which creates challenges for wood in service. In the non-decayed furfurylated samples, the mean accessibility was $6.4 \pm 0.3 \mathrm{mmol} / \mathrm{g}$ (Fig. 2), similar to the data in Fig. 1. Interestingly, the hydroxyl accessibility in the furfurylated samples (mean WPG 32.1\%) increases to levels around $10-12 \mathrm{mmol} / \mathrm{g}$ at $1-2 \%$ mass loss. After this initial increase, the hydroxyl accessibility was around $10 \mathrm{mmol} / \mathrm{g}$ for mass losses up to $20 \%$. It is reasonable to assume that the decay mass loss is occurring in the wood cell wall

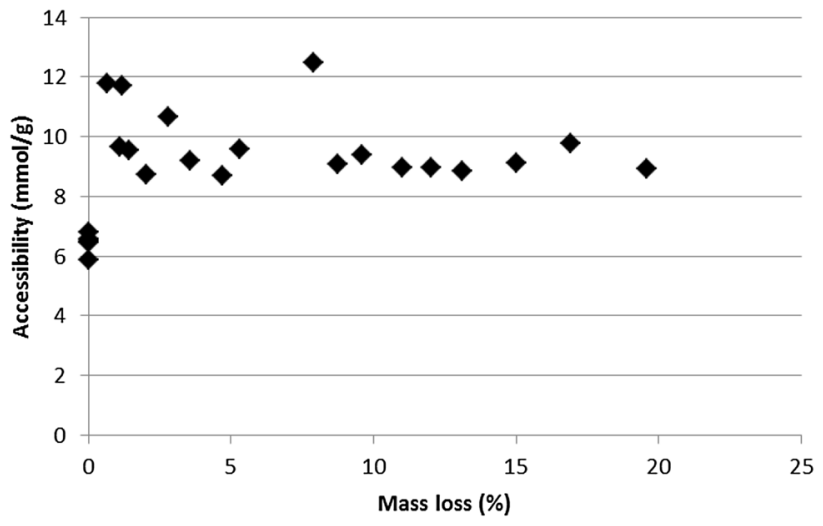

Fig. 2 Hydroxyl accessibility reported per unit cell wall mass for furfurylated samples (WPG 32.1 \pm 2.0 ) at different stages of $R$. placenta mass loss 
components, rather than the furfuryl alcohol-based polymer, since furfurylation does provide decay protection and the carbon-carbon bonds of the furfuryl polymer are likely to be inert to fungal decay processes. Beck et al. (2018) found that $\mathrm{OH}$ accessibility for unmodified wood was relatively stable during $R$. placenta degradation up to $50 \%$ mass loss, ranging from $6.5-8 \mathrm{mmol} / \mathrm{g}$. Removal of hydrophilic hemicellulose and amorphous cellulose during brown rot decay (Winandy and Morrell 1993) would suggest a decrease in OH accessibility during degradation. Beck et al. (2018) attributed the observed stable $\mathrm{OH}$ accessibility to the counterbalancing effects of accessibility decrease due to amorphous polysaccharide removal and accessibility increases due to two mechanisms: 1) opening of cellulose microfibrils and 2) the formation of new $\mathrm{OH}$ groups caused by oxidative alteration of lignin. The same $\mathrm{OH}$ accessibility increasing mechanisms may also occur in the furfurylated samples. The opening of cellulose microfibrils would cause crystalline $\mathrm{OH}$ content to become accessible to deuterated water. However, it seems unlikely that this loss of crystallinity would be more pronounced in furfurylated wood than in unmodified wood. Instead, the second mechanism of new $\mathrm{OH}$ group formation may be responsible for the large $\mathrm{OH}$ accessibility increase. The hydroxyl radicals produced by Fenton chemistry during initial brown rot decay depolymerise wood polysaccharides and modify lignin (Arantes and Goodell 2014). This altered lignin is demethylated (Filley et al. 2002), which increases $\mathrm{OH}$ content. Moreover, the inter-monomer ether linkages in brown rot modified lignin are reduced by more than half and potentially converted to $\mathrm{OH}$ containing residues (Yelle et al. 2011). The monomeric unit in the furfuryl polymer contains an ether linkage in the furan ring. If these ether bonds are cleaved by hydroxyl radicals produced by Fenton chemistry, the residues may contain $\mathrm{OH}$ groups and thus increase the $\mathrm{OH}$ content. Since the cleavage of these bonds would occur only within the monomers and not between the polymeric linkages, the polymer itself would remain intact. Thus, the modified furfuryl polymer would remain entangled within the cell wall matrix.

\section{Conclusion}

The use of deuterium exchange to measure accessible $\mathrm{OH}$ groups in furfurylated wood at different WPGs and at different levels of mass loss caused by exposure to the brown-rot fungus Rhodonia placenta showed that:

- $\mathrm{OH}$ accessibility in sound, furfurylated samples did not change with increasing WPGs, suggesting little crosslinking occurs between the furfuryl polymer and the wood cell wall.
- $\mathrm{OH}$ accessibility in furfurylated samples at commercial treatment level increased significantly after initiation of decay. This increase is attributed to opening of crystalline cellulose regions and formation of new $\mathrm{OH}$ groups in lignin and the furfural polymer due to oxidative alteration.

Acknowledgements Eva Grodås is acknowledged for performing many of the deuterium exchange analyses. This project was financed by The Research Council of Norway 243663/E50 BioMim.

\section{Compliance with ethical standards}

Conflict of interest On behalf of all authors, the corresponding author states that there is no conflict of interest.

Open Access This article is distributed under the terms of the Creative Commons Attribution 4.0 International License (http://creativeco mmons.org/licenses/by/4.0/), which permits unrestricted use, distribution, and reproduction in any medium, provided you give appropriate credit to the original author(s) and the source, provide a link to the Creative Commons license, and indicate if changes were made.

\section{References}

Arantes V, Goodell B (2014) Current understanding of brown-rot fungal biodegradation mechanisms: a review. In: Schultz TP, Goodell B, Nicholas DD (eds) Deterioration and protection of sustainable biomaterials. ACS Symposium Series, Vol. 1158, pp 3-21

Beck G, Strohbusch S, Larnøy E, Militz H, Hill C (2017) Accessibility of hydroxyl groups in anhydride modified wood as measured by deuterium exchange and saponification. Holzforschung 72(1):17-23

Beck G, Thybring EE, Thygesen LG (2018) Brown-rot fungal degradation and de-acetylation of acetylated wood. Int Biodeter Biodegr 135:62-70

EN 84 (1997) Wood preservatives. Accelerated ageing of treated wood prior to biological testing: leaching procedure. European Committee for Standardisation, Brussels

Filley TR, Cody GD, Goodell B, Jellison J, Noser C, Ostrofsky A (2002) Lignin demethylation and polysaccharide decomposition in spruce sapwood degraded by brown rot fungi. Org Geo Chem 33(2):111-124

Popescu C-M, Hill CAS, Curling S, Ormondroyd G, Xie Y (2014) The water vapour sorption behaviour of acetylated birch wood - how acetylation affects the sorption isotherm and accessible hydroxyl content. J Mater Sci 49(5):2362-2371

Winandy JE, Morrell JJ (1993) Relationship between incipient decay, strength, and chemical composition of Douglas-fir heartwood. Wood Fiber Sci 25(3):278-288

Yelle DJ, Wei D, Ralph J, Hammel KE (2011) Multidimensional NMR analysis reveals truncated lignin structures in wood decayed by the brown rot basidiomycete Postia placenta. Environ Microbiol 13(4):1091-1100

Publisher's Note Springer Nature remains neutral with regard to jurisdictional claims in published maps and institutional affiliations. 